\title{
STATUS OF INFESTATION AND BIOLOGY OF PEPPER FRUIT FLY, Atherigona orientalis (Schiner) (DIPTERA: MUSCIDAE)
}

\author{
Febrina Herawani $^{1}$, Aunu Rauf ${ }^{2}$, \& Sugeng Santoso ${ }^{2}$ \\ ${ }^{1}$ Entomology Study Program, Graduate School, Bogor Agricultural University, Indonesia \\ ${ }^{2}$ Department of Plant Protection, Faculty of Agriculture, Bogor Agricultural University, Indonesia \\ Jl. Kamper Kampus IPB Darmaga Bogor 16680 \\ E-mail: aunu@indo.net.id
}

\begin{abstract}
Status of infestation and biology of pepper fruit fly, Atherigona orientalis (Schiner) (Diptera: Muscidae). Numerous muscid flies Atherigona orientalis (Schiner) (Diptera: Muscidae) emerged from fruit fly-infested pepper fruits. Research was conducted to determine the status of infestation of $A$. orientalis on pepper fruits, and to study its biology. Field survey was conducted in the pepper fields in Bogor, whereas study on its biology was done in laboratory. Field surveys showed that flies emerged from fruit fly-infested fruits consisted of $86.1 \%$ A. orientalis, $4.8 \%$ Bactrocera dorsalis (Hendel) (Diptera: Tephritidae), and $9.1 \%$ lonchaeid fly (Diptera: Lonchaeidae). Fruits yielding only $A$. orientalis represented $79.7 \%$ of the infested fruits. The number of $A$. orientalis flies emerged per fruit ranged 1-24, with an average of 3.5 individuals. Laboratory study showed incubation period of eggs was $1.62 \mathrm{~d}$, larva development lasted $11.93 \mathrm{~d}$, and pupa $5.08 \mathrm{~d}$. Longevity of female adult was 32.85 $\mathrm{d}$ and male $31.40 \mathrm{~d}$. The number of eggs laid by a single female ranged $12-191$, with an average of 83.80 . Net reproductive rate $\mathrm{R}_{0}=36.052$, intrinsic rate of increase $\mathrm{r}_{\mathrm{m}}=0.136$, mean generation time $\mathrm{T}=26.482$, doubling time $\mathrm{D}_{\mathrm{t}}=5.098$, and finite rate of increase $\lambda=1.145$. Overall, our research indicated that $A$. orientalis can be a primary pest of pepper fruits, with a high potential of population increase.
\end{abstract}

Key words: Atherigona orientalis, fruit fly, pepper

\section{INTRODUCTION}

Pepper is one of the important horticultural crops in Indonesia. Nationwide, its productivity for the past 5 years is about 6 ton/ha. To fullfill monthly needs of urban communities, it requires about $11,000 \mathrm{ha}$ /month of harvested area of pepper. However, during party season such as Idul Fitri about 12,100-13,300 ha/month of harvested area is needed (Kementerian Pertanian, 2016). Major obstacles of pepper cultivation are plant pests and diseases, and one of them is the fruit fly. The principal fruit fly species infesting chilli pepper fruit in Indonesia has been considered to be Bactrocera dorsalis (Hendel) (Diptera: Tephritidae) (Kalshoven, 1981; Nismah \& Susilo, 2008). Other fruit fly species reported infesting chilli pepper in Malaysia(Vijaysegaran \& Osman, 1991), Thailand (Wingsanoi et al., 2013), and Hawaii (Vargas \& Nishida, 1985) is B. latifrons Hendel. In recent years, from samples of chilli pepper showing fruit fly infestation, numerous smaller yellowish flies emerged from the infested fruits. Further examination of these specimens revealed them to be Atherigona orientalis (Schiner) (Diptera: Muscidae).
Geographic distribution of $A$. orientalis is mainly pantropical, found within $20^{\circ}$ north and south of the equator (Skidmore, 1985), which include various countries in Asia, Africa, America, Australia, and Oceania region (Suh \& Kwon, 2016). Outside of that range it has been reported from Korea (Suh \& Kwon, 2016), China, Florida, California, Texas (Hibbard \& Overholt, 2013), and Argentina (Patitucci et al., 2012). A. orientalis is highly polyphagous. Larvae feed and develop on decaying plant materials, feces, and carrion (Bohart \& Gressitt, 1951; Pont, 1986; Pont \& Magpayo, 1995). Because of its food preferences and abundance, A. orientalis is considered to be an important species in the transmission of faecal pathogens and filth-borne diseases (Bohart \& Gressitt, 1951). Larva of $A$. orientalis is facultatively predacious on living larvae of other insects including B. cucurbitae (Coquillett) (Yamamura \& Iwahashi, 1982).

Major host plants of $A$. orientalis include cabbage and cauliflower (Brassica oleraceae L.), pepper (Capsicum spp.), orange (Citrus spp.), melon (Cucumis melo L.), tomato (Lycopersicon esculentum Mill.), beans (Phaselous spp.), and sorghum (Sorghum 
bicolor (L.)) (Hibbard \& Overholt, 2013). Other host plants are bitter gourd (Momordica charantia L.), sponge gourd (Luffa cylindrica (L.) Roem.), eggplant (Solanum melongena L.), mango (Mangifera indica L.) (Kalshoven, 1981; Suputa et al., 2010), and soursop (Annona muricata L.) (Ogbalu et al., 2016).

There are many records of $A$. orientalis reared in plants attacked by other insect pests (Pont \& Magpayo 1995; Kalshoven, 1981). Thus A. orientalis could be considered a secondary pest. However, it can sometimes be a primary pest of certain agricultural crops in the family Solanaceae (Hibbard \& Overholt, 2013). Ogbalu $\&$ Bob Manuel (2014) reported that $A$. orientalis is a major primary pest of bell pepper in Nigeria, and for that reason $A$. orientalis is called pepper fruit fly (Hibbard \& Overholt, 2013; CABI, 2018).

Although our preliminary survey and previous studies (Kalshoven, 1981; Suputa et al., 2010) reported numerous $A$. orientalis flies emerged from fruit flyinfested pepper fruits, the status of $A$. orientalis whether as a primary or secondary pest is not known. Likewise, not much information available on the biology of $A$. orientalis. Study was conducted with the objectives (1) to determine the status of infestation of A. orientalis on pepper fruit, and (2) to study its life cycle and population growth parameters.

\section{MATERIALS AND METHODS}

Research Sites. Surveys were conducted in the red and curly pepper fields in Villages of Tenjolaya (Subdistrict Tenjolaya), Rancabungur (Subdistrict Rancabungur), Dramaga (Subdistrict Dramaga), Megamendung (Subdistrict Megamendung) of the District of Bogor; Bantarkemang (Subdistrict East Bogor) of the Municipality of Bogor; Cipanas (Subdistrict Cipanas) of the District of Cianjur. Insect rearing was done in the laboratory under room temperature of 25$27{ }^{\circ} \mathrm{C}$ and relative humidity $(\mathrm{RH})$ of $60 \%$. Research was conducted from November 2016 until December 2017.

Field Surveys. Surveys were conducted in two stages. The first stage was to determine the level of infestation of fruit fly. For this purpose, pepper field plots (each $100-500 \mathrm{~m}^{2}$ ) showing fruit fly infestation were selected, and all uninfested (healthy) and infested pepper fruits were counted and recorded. The second stage was to determine fly species composition that emerged from the infested fruits. For this purpose, 50 fruit fly-infested fruits from each selected field were picked and put into the plastic bag with a label of the date and location, and brought to laboratory for adult emergence. Each infested pepper fruit was separately kept in the plastic glass (diameter $=9 \mathrm{~cm}$, height $=12 \mathrm{~cm}$ ) containing moist sterile sawdust at the base as a place for pupation. Flies emerged from the pupae were counted, recorded, and identified. Identification of Tephritidae was based on pictorial keys provided by the Plant Health Australia (2018), and of Muscidae based on Pont \& Magpayo (1995), Moophayak et al. (2011), and Suh \& Kwon (2017).

Biology of $A$. orientalis. Some of flies emerged from the infested fruits were used for life cycle study. For this purpose, 20 pairs of $A$. orientalis were collected and each pair was placed in a cylindrical plastic cage (diameter $=10 \mathrm{~cm}$, height $=20 \mathrm{~cm})$. The lid of each cage had a hole $(4 \times 4 \mathrm{~cm})$ which was covered with organdi cloth as a ventilation. On the lower surface of the lid, a cotton wool was suspended inside the cage with the aid of a string. The cotton was moistened daily with a mixture of yeast, powdered sugar, and water (1:1:5) as food for adults. In addition, a mixture of yeast and powdered sugar (1:1) was also placed in the petri dish (diameter $=4 \mathrm{~cm}$ ) as food. For oviposition site a fresh green pepper fruit, with a stalk submerged in the water filled-glass vial (diameter $=1.5 \mathrm{~cm}$, height $=5.5$ $\mathrm{cm}$ ), was placed inside the cages. Each vial was placed in the middle of little plastic container and filled with cotton to make it stay firmly. The pepper fruit was replaced daily with the fresh one. The number of eggs laid by each female, as well as adult mortality were recorded every day.

To observe development of immature stages, 5 eggs laid by each 20 adults were left intact on the calyx. Therefore, the total number of eggs used for this study were 100 eggs. The development of eggs were observed every day until the eggs hatched, characterized by the presence egg shells. The $1^{\text {st }}$ instar larvae, which fed and developed inside pepper fruits, were reared until the $3^{\text {rd }}$ instar larvae exited from the fruits. Those emerged $3^{\text {rd }}$ instar larvae were observed every day until pupation. Pupae were transferred into a transparent plastic container $($ diameter $=6.5 \mathrm{~cm}$, height $=4.5 \mathrm{~cm})$ and observed every day until adult emergence.

Data Analysis. Data on fruit fly infestation were tabulated based on sampling locations. Composition of fruit fly species emerged from the infested fruits was presented on the basis of sampling location and varieties of pepper. In addition, fruit flies emerged from the infested fruits were separated into those single (only one species) and mixed infestation (more than one 
species). If only $A$. orientalis emerged from an infested pepper fruits, it suggested that A. orientalis was a primary pest of pepper fruit. The immature developmental time, longevity of adults, and fecundity were presented as $\bar{\chi}_{ \pm}$SE. Data of survivorship and daily fecundity was built into a fertility table, and combined with immature developmental time to determine various population growth parameters. Those parameters were net reproduction, $\mathrm{R}_{0}=\Sigma \mathrm{l}_{\mathrm{x}} \mathrm{m}_{\mathrm{x}}$; intrinsic rate of increase, $r_{m}=\sum 1_{x} m_{x} \exp \left(r_{m} x\right)=1$; mean generation time, $\mathrm{T}=\sum \ln \left(\mathrm{R}_{0}\right) / \mathrm{r}_{\mathrm{m}}$; finite rate of increase, $\lambda=\exp \left(\mathrm{r}_{\mathrm{m}}\right)$; and doubling time, $\mathrm{D}_{\mathrm{t}}=\ln (2) / \mathrm{r}_{\mathrm{m}}$ (Birch, 1948). Mean and variance of all those parameters were analyzed using LIFETABLE.SAS (Maia et al., 2000) with the help of statistical package SAS version 9.0 for MS Windows.

\section{RESULTS AND DISCUSSION}

Status of Infestation Infestation Level and Fly Species Composition. Our field survey showed that the infestation level of fruit flies in the pepper fields ranged 2\% in Megamendung and 16\% in Rancabungur (Table 1). Herlinda et al. (2007) reported infestation level of $13.2 \%$ in Lahat District, South Sumatera. Such data represented infestation level occurred only at a specific date. In the fields, fruit fly infestation continues during growing season, and thus the cumulative infestation levels kept increasing. In addition, the infested pepper fruits generally fall to the ground and are not usually counted. Therefore, the cumulative yield losses must be higher than those predicted from a single observation. Hasyim et al. (2014) reported that yield losses of pepper caused by the fruit flies ranged from 20 until $60 \%$.

There were 598 flies emerged from the infested pepper fruits, with $A$. orientalis having the highest proportion $(86.1 \%)$, followed by lochaeid flies $(9.1 \%)$ and B. dorsalis (4.8\%) (Table 2). In each location, both for curly and red peppers, $A$. orientalis always showed the highest proportion of all the flies emerged from the fruits. This is in contrast with the current opinion that $B$. dorsalis was the main insect pest causing damage to pepper fruits. In fact, the proportion of fruits infested by $B$. dorsalis ranged $0-10 \%$. In this study, we did not collect samples from the hot chilli pepper (Capsicum futescens $\mathrm{L}$.) since it was rarely infested by $B$. dorsalis. According to Ogbalu (1989), hot chilli pepper was not preferred by $A$. orientalis for oviposition. Similarly, Suputa et al. (2010) reported that more $A$. orientalis flies emerged from red pepper. In Nigeria, A. orientalis was reported to be the major pest of bell pepper that cause yield losses up to $93.5 \%$ in certain varieties (Ogbalu et al., 2005c).

Single and Mixed Infestation. Based on 158 infested fruits, 126 fruits (79.7\%) yielded only A. orientalis, 6

Table 1. Level of fruit fly infestation in various pepper fields in Bogor

\begin{tabular}{lcccc}
\hline Villages & Field size $\left(\mathrm{m}^{2}\right)$ & $\begin{array}{c}\text { Observed } \\
\text { fruits }\end{array}$ & $\begin{array}{c}\text { Infested } \\
\text { fruits }\end{array}$ & $\begin{array}{c}\text { Level of } \\
\text { infestation (\%) }\end{array}$ \\
\hline Bantarkemang & 300 & 2281 & 121 & 5.3 \\
Tenjolaya & 250 & 377 & 44 & 11.67 \\
Megamendung & 500 & 8802 & 211 & 2.4 \\
Rancabungur & 250 & 473 & 77 & 16.28 \\
Darmaga & 100 & 129 & 15 & 11.63 \\
\hline
\end{tabular}

Table 2. Composition of species of flies emerged from infested fruits $(n=50$ fruit samples from each village)

\begin{tabular}{lccccc}
\hline \multirow{2}{*}{ Villages } & \multirow{2}{*}{ Pepper cultivars } & \multicolumn{3}{c}{ Species* } & \multirow{2}{*}{ Total } \\
\cline { 3 - 5 } & & A. orientalis & B. dorsalis & Lonchaeidae & \\
\hline Cipanas & Curly & $56(96.6)$ & 0 & $2(3.5)$ & 58 \\
Bantarkemang & Curly & $30(96.8)$ & $1(3.2)$ & 0 & 31 \\
Tenjolaya & Red & $76(71.0)$ & $11(10.3)$ & $20(18.7)$ & 107 \\
Megamendung & Curly & $61(72.6)$ & $8(9.5)$ & $15(17.9)$ & 84 \\
Rancabungur & Red & $267(91.1)$ & $9(3.1)$ & $17(5.8)$ & 293 \\
Dramaga & Curly & $25(100.0)$ & 0 & 0 & 25 \\
\hline Total & & $515(86.1)$ & $29(4.8)$ & $54(9.1)$ & 598 \\
\hline
\end{tabular}

* numbers in parentheses indicates percentage (\%). 
fruits $(3.8 \%)$ only $B$. dorsalis, and 4 fruits $(2.5 \%)$ only lonchaeid flies (Figure 1). Mixed infestations occurred on 6 fruits $(3.8 \%)$ by $A$. orientalis and B. dorsalis, 10 fruits $(6.3 \%)$ by $A$. orientalis and lonchaeid flies, 1 fruit $(0.6 \%)$ by $B$. dorsalis and lonchaeid flies, and 5 fruits (3.2\%) by all three species of flies. A high percentage of pepper fruits yielded only $A$. orientalis showed that the insect can infest the pepper fruits without being accompanied or preceded by $B$. dorsalis or other species. This might indicate that $A$. orientalis can be a primary pest on pepper fruits as previously reported on bell pepper in Nigeria (Ogbalu \& Bob Manuel, 2014). According to Ogbalu (1989) during heavy infestation whih was generally occured in the rainy season, $A$. orientalis attacked both unripe and ripe pepper fruits. Heavy infestation of $A$. orientalis was related to use of chicken droppings as manure that attractive to $A$. orientalis flies (Iheagwam \& Nwankiti, 1980).

Not only on pepper, A. orientalis has been reported to be a primary pest of several commodities. In Australia, A. orientalis is listed as a primary pest on tomato fruit because the female will lay eggs in the cracks of the fruit and the developing larvae will ruin the fruit (Queensland Government, 1998). Ogbalu et al. (2005c) reported that infestation level of A. orientalis on tomatoes in Nigeria reached 51\%. Infestation level of A. orientalis on melon fruits in Pakistan ranged from 25 until 85\% (Chughtai et al., 1985). Status of $A$. orientalis as a primary pest on melon had been reported earlier in Florida by Butcher (1954).

Based on observation of 148 fruits infested only by A.orientalis, the number of flies emerged per infested fruit varied from 1 until 24 with an average of
3.5 flies (Figure 2). Eighty two or $55 \%$ of infested fruits yielded 1-2 flies. Further examination on raw data indicated that number of emerged flies seemed to depend on size of fruits. On average, $2.0 \pm 0.1$ flies emerged from curly pepper, while from red pepper having larger size the number of emerged flies doubled to $4.9 \pm 0.6$ flies. Differences in level of infestation among varieties are related to morphological factors such as shape, size, and colour, nature of calyx, and presence/absence of grooves (Ogbalu, 1989). The number of emerged flies indicates the total number of eggs laid per fruit. Ogbalu et al. (2005a) found the average number of egg was 75 eggs per 15 fruits, which was generally laid on calyx of fruit. On melon, $A$. orientalis laid 15-95 eggs per fruit (Chughtai et al., 1985).

Biology of $A$. orientalis Morphology. Laboratory observation showed that $A$. orientalis egg is white in colour and cylindrical in shape. It measures about 0.82 $\mathrm{mm}$ long and $0.20 \mathrm{~mm}$ wide. A number of parallel ridges run on the dorsal surface of the egg (Figure 3A). The ridges converge posteriorly, but at the anterior end of the egg remains tightly fitted with a thin lid. On the midventral side of the egg, a flat area is present with a pattern of small hexagonal markings. Generally, those descriptions are similar to A. oryzae Malloch egg described by Srivastava \& Pandey (1968).

We did not make a detailed observation of the larval development, but it is known that $A$. orientalis has three larval instars (Couri \& de Araujo, 1992; Grzywacz \& Pape, 2014). According to Skidmore (1985) the first and second instar larvae are small and undescribed. The third instar larvae, which have just

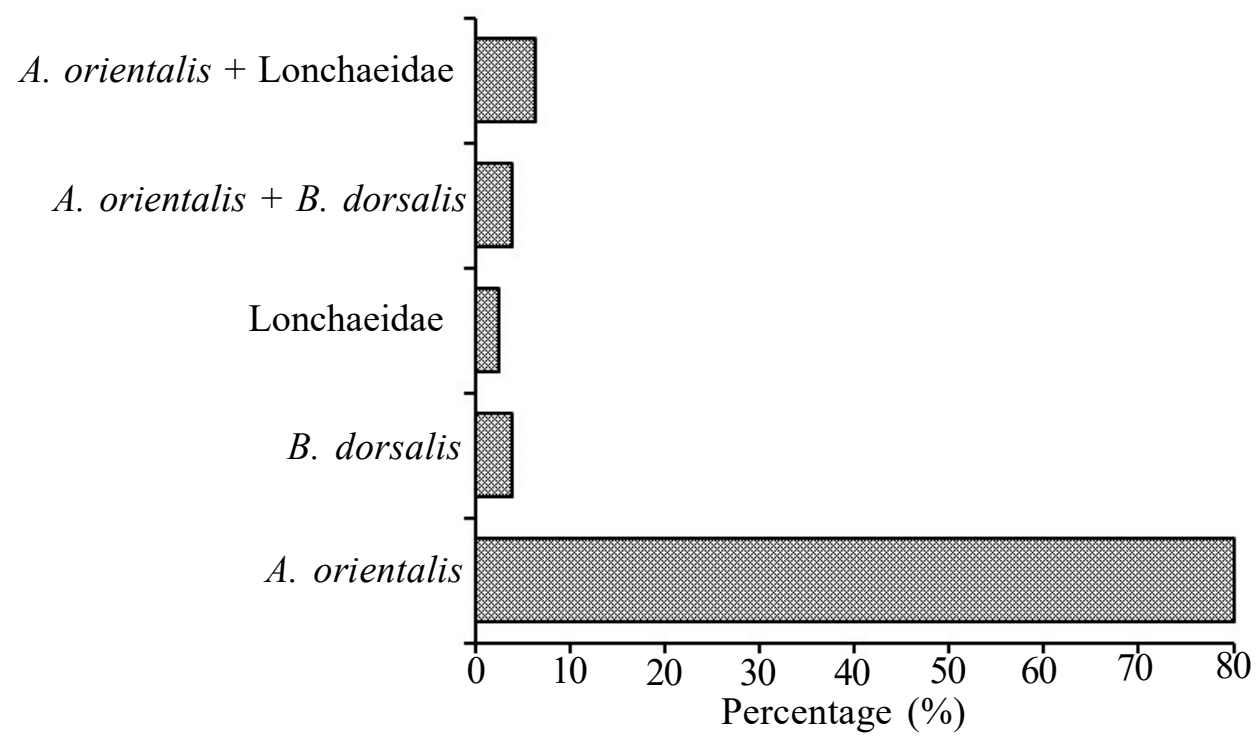

Figure 1. Proportion of pepper fruits infested by single and mixed species of flies 
emerged from the infested fruit, measured $7.78 \mathrm{~mm}$ long and $0.95 \mathrm{~mm}$ wide (Figure 3B). A full description of larvae has been given by several authors (Bohart \& Greesitt, 1951; Skidmore 1985; Couri \& de Araujo 1992; Grzywacz \& Pape, 2014). In laboratory rearing, the mature third instar larvae pupated in sawdust. In the

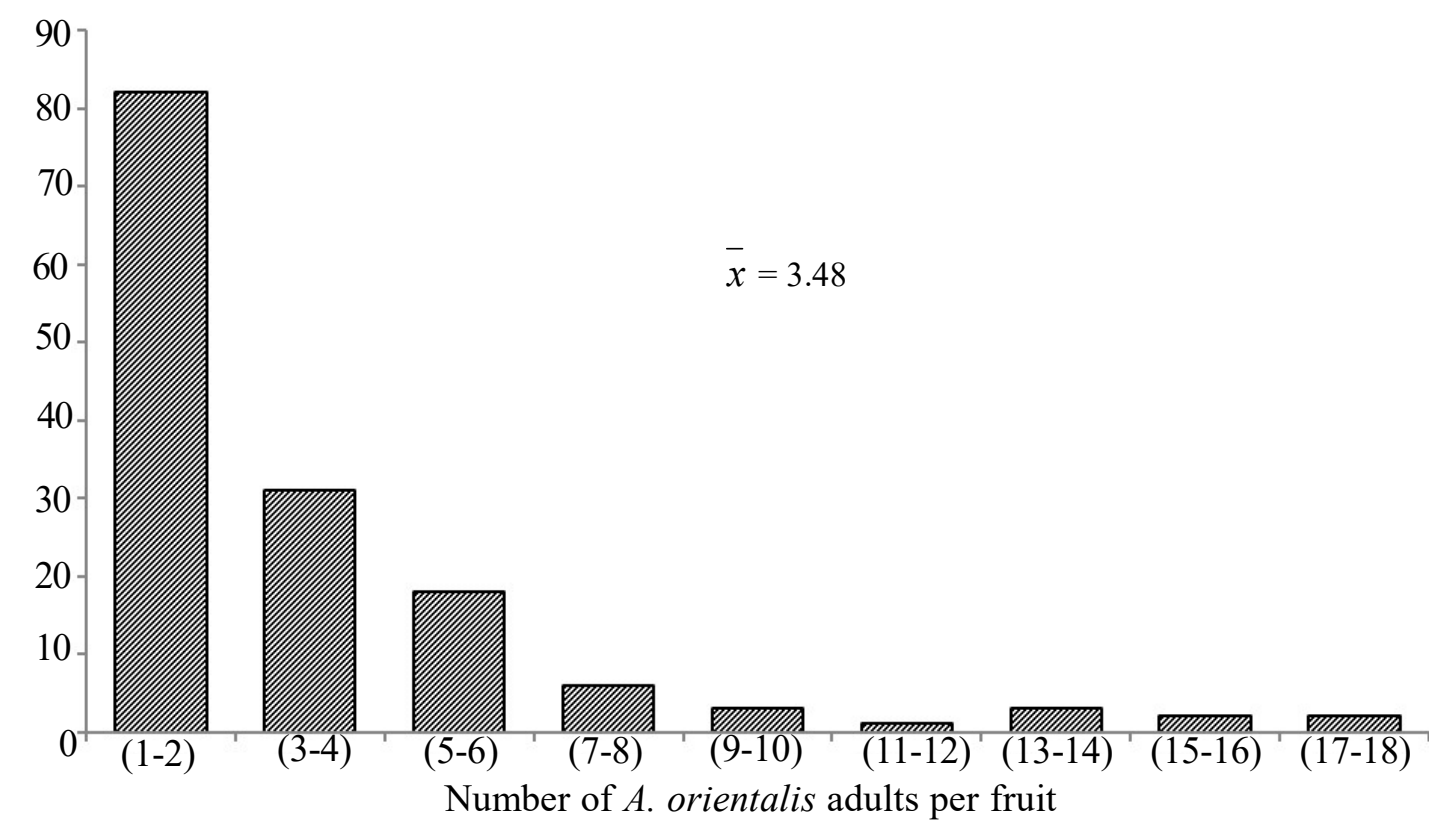

Figure 2. Frequency of infested pepper fruits based on the number of flies emerged per fruit
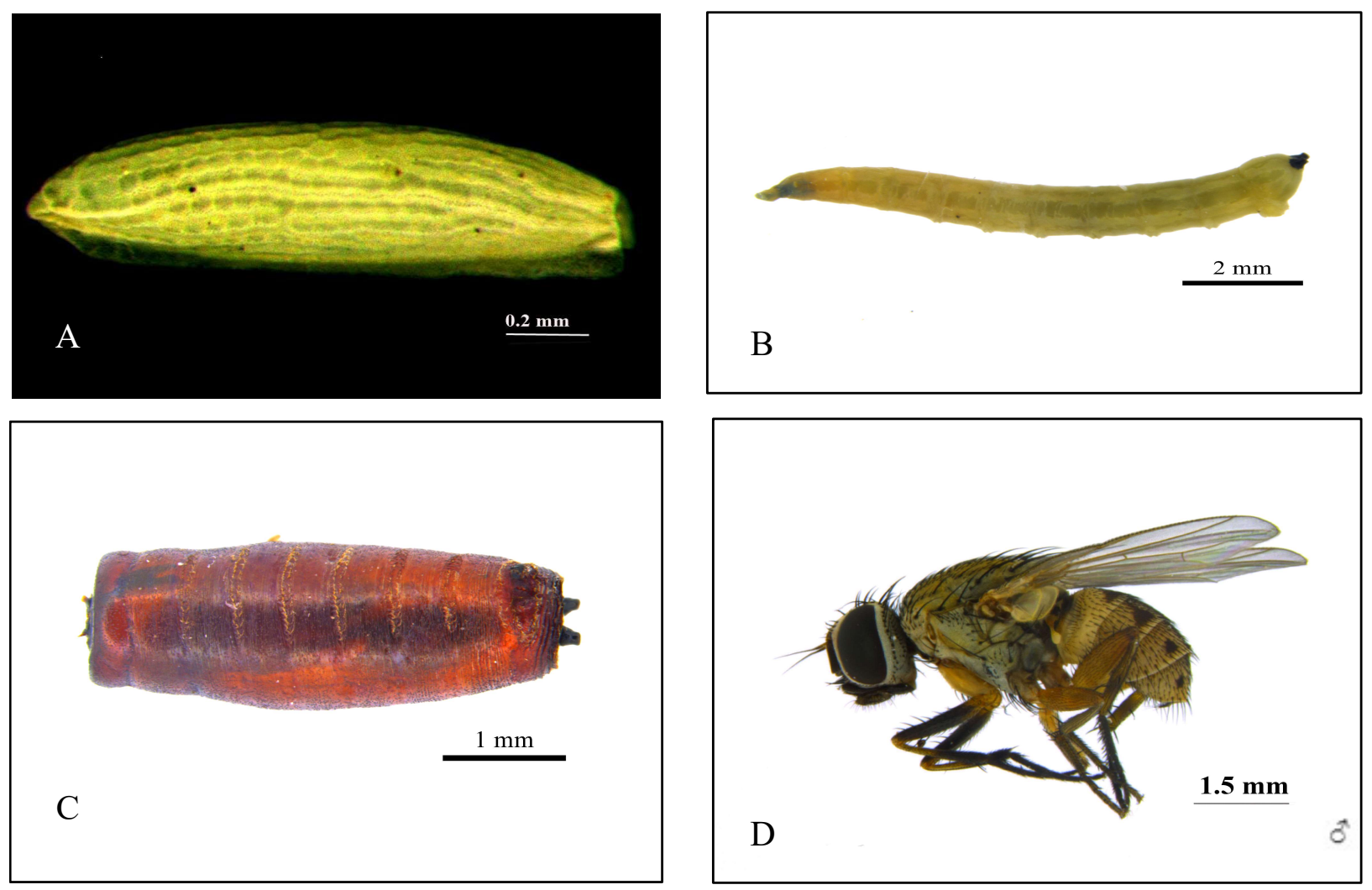

Figure 3. Atherigona orientalis: (A) egg, (B) larva, (C) puparium, and (D) adult field, pupation took places in the soil or inside the infested fruits (Ogbalu, 1999).

The puparium was initially light brown, but it becomes dark brown with age (Figure 3C), measured $4.03 \mathrm{~mm}$ long and $1.62 \mathrm{~mm}$ wide, and smaller than $B$. dorsalis pupae $( \pm 6 \mathrm{~mm})$ that also infest pepper fruits. It as slightly tapered at the posterior end where

$\bar{x}=3.48$ 
spiracular lobes are located, but is flat to slightly concave on the anterior end.

In general, adult of $A$. orientalis looks similar to housefly, Musca domestica L., but it is smaller. Malviya et al. (2015) reported that both species had a genetic similarity. A. orientalis adult has grey thorax, yellowish abdomen, and two pair black small dot in the dorsal abdomen (Figure 3D). The male and female flies can be easily distinguished by size. The male was $2.92 \mathrm{~mm}$ long and $1.28 \mathrm{~mm}$ wide. The female is slightly larger than the male, the body was $3.35 \mathrm{~mm}$ long and $1.57 \mathrm{~mm}$ wide.

Life Cycle. The immature developmental time of $A$. orientalis is presented in Table 3 . The incubation period of eggs was 1.62 days. The developmental periods of larvae and pupae were 12 and 5 days, respectively. Therefore, their total developmental period from egg until adult emerged was 18.63 days. Chughtai et al. (1985), who studied A. orientalis on melon, reported the incubation period of eggs was from 36 to 58 hours, the larval period was 7 to 8 days, and the pupal period lasted for 5-6 days. The results are in conformity with observations on other species. Sileshi (1997) studied the biology of $A$. hyalinipennis van Emden on a cereal Eragrostis tef (Zucc), and reported that the average incubation period of eggs, developmental periods of larvae and pupae were 3, 10-15, and 8-11 days, respectively, with a total immature developmental period was 25.34 days. Karibasavaraja et al. (2007) studied A. soccata Rondani on sorghum and found that the egg incubation period was 2.10 days, duration of larval and pupal stages were 9.10 and 8.50, respectively; and total immature developmental period was 20.4 days.
From a total of 100 eggs of A.orientalis incubated, only 60 eggs hatched into larvae. The remaining of 40 eggs did not hatch that might be laid by unmated females. All those 60 larvae survived until become adults, with a sex ratio of male to female was of 1:0.77. The longevity of male adults was 31.4 days ranging from 12-41 days, while female adults lived 32.8 days ranging from $20-44$ days. The preoviposition period was 5.7 days and oviposition period was 16.2 days. Ogbalu et al. (2005b) found the longevity of male and female adults, preoviposition period, and oviposition period was shorter than those in our study, i.e. male 7.4 days, female 14.5 days, preoviposition 1.7 days, and oviposition 8.9 days. These differences might be due to different laboratory temperature and food composition for adults used in the experiment (Ogwaro, 1978).

A single female of $A$. orientalis laid 12-191 eggs with an average of 83.8 eggs during its entire life span (Table 3). This is less than those reported by Ogbalu et al. (2005b) who found 2465 eggs from 21 female adults or average fecundity was 117.4 eggs per female. Studies by earlier workers also showed a variation in fecundity. Raina (1982) reported an average fecundity of $A$. soccata was 78.4 eggs, while Ogwaro (1978) found a slightly lower (62.8 eggs) for the same species. In contrast, Meksongsee et al. (1978) reported that an average fecundity of $A$. soccata in Thailand was 235 eggs per female. The variation in fecundity could be due to differences in duration of exposure, length of time to locate the host plant, adult longevity, food sources for adults (Nwanze et al., 1998), and preference for host plants (Ogbalu et al., 2005a).

Under laboratory condition, eggs were laid singly or in cluster on the calyx or pedicle (stalk) of fruits. We

Table 3. Development period (day) and fecundity of Atherigona orientalis

\begin{tabular}{lccc}
\hline \multicolumn{1}{c}{ Stadia Immature } & $\mathrm{n}$ & Range & $\bar{X} \pm \mathrm{SE}$ \\
\hline Egg & 60 & $1-2$ & $1.62 \pm 0.05$ \\
Larva & 60 & $9-17$ & $11.93 \pm 0.29$ \\
Pupa & 60 & $3-8$ & $5.08 \pm 0.19$ \\
Total of immature development & 60 & $15-24$ & $18.63 \pm 0.27$ \\
Adult & & \\
Male & 20 & $12-41$ & $31.40 \pm 2.06$ \\
Female & 20 & $20-44$ & $32.85 \pm 1.51$ \\
Preoviposition & 19 & $2-19$ & $5.79 \pm 1.19$ \\
Oviposition & 19 & $4-31$ & $16.16 \pm 1.81$ \\
Postoviposition & 19 & $0-26$ & $11.37 \pm 1.91$ \\
Fecundity* (eggs/female) & 19 & $12-191$ & $83.80 \pm 11.92$ \\
\hline
\end{tabular}

*One female laid only one egg and not included in estimating fecundity 
did not find eggs on smooth surface of fruit. Ogbalu et al. (2005a) who studied oviposition prefrences of A. orientalis on bell pepper, found most of the eggs (40-75\%) were laid on the calyx and the rest on grooves.

Survivorship and Daily Fecundity. Daily survivorship curve $\left(1_{\mathrm{x}}\right)$ of $A$. orientalis showed type I (Figure 4) characterized by high age-specific survival probability in early and middle life, followed by a rapid decline in survival in later life. Fly mortality started at 21-day-old and then increased with the inceasing of age. Daily reproduction curve showed that oviposition period occurred when females were 2 until 34 days old. Average number of eggs laid per day $\left(\mathrm{m}_{\mathrm{x}}\right)$ fluctuated, with the highest peak (8.3 eggs) occurred at 9-day-old females (Figure 4). Other peaks of oviposition occurred at $4,12,16,20,22$, and 27 days old females. Examination on raw data showed that a female laid a maximum 58 eggs per day, and after that the female quited ovipositing for 2-3 days. Such a substantial fluctuations of egg laying was also reported for Synthesiomyia nudiseta (Wulp)
(Diptera: Muscidae) (Rabinovich, 1970; Aruna et al., 2011).

Parameters of Population Growth. Various population growth parameters which include net reproduction $\left(\mathrm{R}_{0}\right)$, intrinsic rate of increase $\left(\mathrm{r}_{\mathrm{m}}\right)$, mean generation time $(\mathrm{T})$, doubling time $\left(\mathrm{D}_{\mathrm{t}}\right)$, and finite rate of increase ( ) are presented in Table $4 . R_{0}$ represents the average number of offspring that a female produces during its entire life. In our study, the $\mathrm{R}_{0}$ was 36.052 offspring per female per generation. Parameter $r_{m}$ is the rate of increase per female per day under the constant environment, unlimited resources, and in the absence of external mortality factors. The $\mathrm{r}_{\mathrm{m}}$ of $A$. orientalis under the given condition was $0.136 \mathrm{female} / \mathrm{female} / \mathrm{day}$. The average generation period ( $\mathrm{T}$ ) was 26.482 days. The time required for the population to double in number $\left(\mathrm{D}_{\mathrm{t})}\right.$ was 5.098 days. The finite rate of increase ( ), which is the number of times that the population is multiplied per unit of time, was 1.145. Among all those parameters, $r_{m}$ is the most important parameter obtained from a life table since it allows the comparison of potential increase among

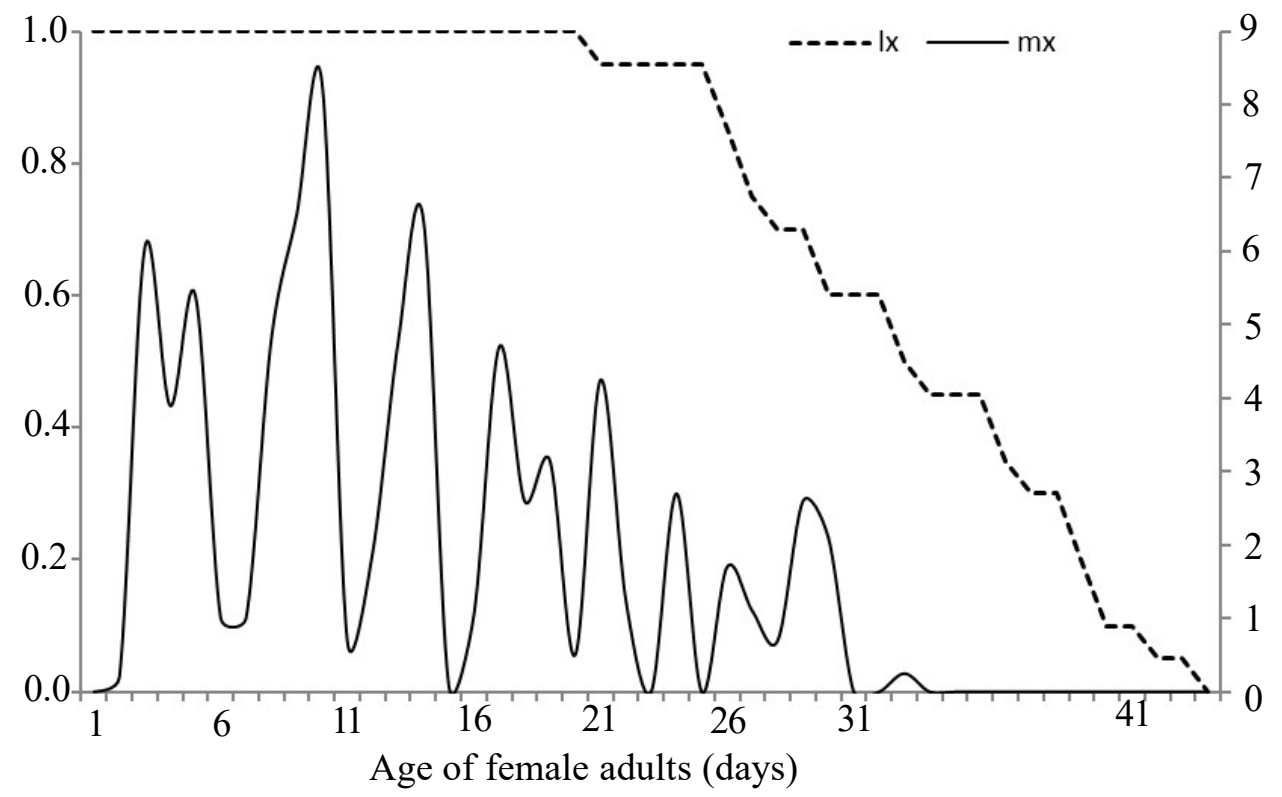

Figure 4. Survivorship and reproduction curve of Atherigona orientalis

Table 4. Population growth parameters of Atherigona orientalis

\begin{tabular}{lrcc}
\hline Parameters & Mean & 95\% Confidence interval & Corresponding unit \\
\hline Ro & 36.052 & $25.128-46.977$ & individual/female/generation \\
$\mathrm{r}_{\mathrm{m}}$ & 0.136 & $0.121-0.149$ & individual/female/day \\
$\mathrm{T}$ & 26.482 & $24.533-28.430$ & days \\
$\mathrm{D}_{\mathrm{t}}$ & 5.098 & $4.555-5.641$ & days \\
$\lambda$ & 1.145 & $1.129-1.162$ & per day \\
\hline
\end{tabular}


species (Birch, 1948). The value of $r_{m}$ in our study is nearly close to those other flies. Rabinovich (1970) reported the $\mathrm{r}_{\mathrm{m}}$ of Synthesiomyia nudiseta fly (Wulp) (Diptera: Muscidae) was 0.11 and 0.18 , respectively under temperature $20^{\circ} \mathrm{C}$ and $28^{\circ} \mathrm{C}$.

Is $A$. orientalis a Primary Pest? A. orientalis is usually considered as secondary pest, since it is typically found in already damaged fruits, acting as a saprophagous (Pont \& Magpayo, 1995). However, it can sometimes be a primary pest of certain agricultural crops, such as on cantaloupe in Florida (Butcher, 1954), melon in Pakistan (Chughtai et al., 1985), and bell pepper in Nigeria (Ogbalu \& Bob Manuel, 2014). Our field surveys revealed status of $A$. orientalis on chilli pepper in Bogor. There was strong indication that $A$. orientalis can be a primary pest on pepper fruit, as also reported previously on bell pepper in Nigeria (Ogbalu \& Bob Manuel, 2014). This was based on the fact that many fruit fly-infested pepper fruits yielded only $A$. orientalis flies. To ensure that $A$. orientalis is a primary pest on pepper fruit, it would be good to set up an artificial infestation experiment by adding pairs of $A$. orientalis flies into a cage with fruiting-pepper plants inside.

According to Ogbalu et al. (2005a), female of A. orientalis generally laid eggs under the calyx of pepper fruits and at the apical portion of the fruits where the freshly emerging $1^{\text {st }}$ instar larvae make entry into pepper fruits, causing serious damage to both the unripe and ripe fruits. On tomatoes, the eggs were laid as soon as the fruit begins to crack or has any indentations at the flower end (Bohart \& Gressitt, 1951). In cucurbits, the fly oviposited eggs in the wounds left by the ovipositor of $B$. cucurbitae, and it is suspected that the larvae of $A$. orientalis feed on the larvae of B. cucurbitae (Bohart \& Gressitt, 1951; Yamamura \& Iwahashi, 1982).

The increase of fruit fly infestation on pepper fruit caused by $A$. orientalis lately, most likely due to the increasing use of manure and compost in vegetable cultivation. Chilli pepper farmers are generally apply chicken or goat droppings as manure. According to Bohart \& Gressitt (1951) the adults of A. orientalis feeds on a wide variety of substances, including carrion and rotting fruit and vegetables. Ogbalu's study (1999) revealed that plots having received chicken dropping as manure suffered the highest percentage of fruit infestation than plots treated with NPK chemical fertilizer. Furthermore, A orientalis infestation also depend on the pepper varieties grown. Ogbalu (1989) reported a heavy infestation on bell pepper variety of Nsukka Yellow and Ataruga that both varieties have raised calyx, and females of $A$. orientalis preferred to lay eggs on such calyx. In addition to manure and variety, level of infestation was also affected by climate. $A$. orientalis severely attack pepper and tomato fruits mostly during rainy seasons (Ogbalu et al., 2005c). The correlation between climate and level of infestation was also reported on A.soccata (Singh et al., 2018). The high infestation of $A$. orientalis in the pepper fields is an evidence that the species has a potential to increase rapidly, as indicated by all population growth parameters.

\section{CONCLUSION}

Proportion of $A$. orientalis that outnumber other fly species and a high frequency of single infestation indicate that $A$. orientalis can be a primary pest of the pepper fruits. A short life cycle (21 days), a high intrinsic rate of increase $r_{m}(0.136)$, and a polyphagous feeding behavior contribute to the rapid population growth and high infestation of $A$. orientalis in the fields.

\section{ACKNOWLEDGMENTS}

This study was part of the thesis of the first author in fulfilling the requirement for MS degree at the Study Program of Entomology, Graduate School, Bogor Agricultural University.

\section{REFERENCES}

Aruna DA, Abu Hasan A, Kumara TK, \& Che Salmah MR. 2011. Life table of Synthesiomyia nudiseta (Van der Wulp) (Diptera: Muscidae) under uncontrolled laboratory-a preliminary study. Trop. Biomed. 28(3): 524-530.

Birch LC. 1948. The intrinsic rate of natural increase of an insect population. J. Anim. Ecol. 17(1): 1526.

Bohart GE \& Gressitt JL. 1951. Filth-Inhabiting Flies of Guam. Bernice P. Bishop Museum Bulletin, Hawai.

Butcher FG. 1954. A muscid fly, Atherigona orientalis Schin., a pest of cantaloupes. Fla. Entomol. 37(3): 147-148.

CABI. 2018. Atherigona orientalis (pepper fruit fly). In: Invasive Species Compendium. CAB International, Wallingford. www.cabi.org/isc. 
Chughtai GH, Khan S, \& Baloch UK. 1985. A new record of infestation of melon fruits by an anthomyiid fly in Indus River Beach areas of D.I. Khan. Pak. J. Zool. 17(2): 165-168.

Couri MS \& de Araujo PF. 1992. The immature stages of Atherigona orientalis Schiner (Diptera: Muscidae). Proc. Biol. Soc. Wash. 105(3): 490493.

Grzywacz A \& Pape T. 2014. Larval morphology of Atherigona orientalis (Schiner) (Diptera: Muscidae)-A species of sanitary and forensic importance. Acta. Tropica. 137: 174-184.

Hasyim A, Setiawati W, \& Liferdi L. 2014. Teknologi pengendalian hama lalat buah pada tanaman cabai. Iptek Hortikutura. 10: 1-6.

Herlinda S, Mayasari R, Adam T, \& Pujiastuti Y. 2007. Populasi dan serangan lalat buah Bactrocera dorsalis (Herdel) (Diptera=Tephritidae) serta potensi parasitoidnya pada pertanaman cabai (Capsicum annum L.). Prosiding Seminar dan Kongres Ilmu Pengetahuan Wilayah Barat. Palembang.

Hibbard KL \& Overholt WA. 2012. Pepper Fruit Fly Atherigona orientalis (Schiner) (Insecta: Diptera: Muscidae). University of Florida. http:/ /entomology.ifas. ufl.edu/creatures. Accessed 5 January 2017.

Iheagwam EU \& Nwankiti OC. 1980. Dipterous insect pests of pepper, Capsicum spp., in the eastern states of Nigeria. Rev. Zool. Afr. 94(4): 936939.

Kalshoven LGE. 1981. The Pests of Crops in Indonesia. Rev. \& Trans. Van der Laan PA. PT Ichtiar Baru-Van Hoeve, Jakarta.

Karibasavaraja LR, Balikal RA, \& Desphande VP. 2007. Comparative biology of shoot fly, Atherigona soccata Rondani on susceptible and resistant cultivars of sorghum. Agric. Sci. Digest. 27(3): 204-206.

Kementerian Pertanian. 2016. Outlook Komoditas Pertanian Sub Sektor Hortikultura: Cabai Merah. Pusat Data dan Sistem Informasi Pertanian. Kementerian Pertanian.

Maia A De HN, Luis AJB, \& Campanhola C. 2000. Statistical inference on associated fertility life table parameters using jackknife technique: computational aspects. J. Econ. Entomol. 93(2): 511-518.

Malviya S, Tewari RR, \& Agrawal UR. 2015. Genetic relationship between the muscids using RAPDPCR as marker. Int. Res. J. Biol. Sci. 4(1): 6670.

Meksongsee B, Kongkanjana A, Sangkasuwan U, \& Young WR. 1978. Longevity and oviposition of sorghum shoot fly adults on different diets. Ann. Entomol. Soc. Am. 71(6): 852-853.

Moophayak K, Kurahashi H, \& Sukontason KL. 2011. Three new spesies of shoot fly Atherigona spp. from northern Thailand. J. Insc. Sci. 11(1): 139.

Nismah \& Susilo FX. 2008. Keanekaragaman dan kelimpahan lalat buah (Diptera: Tephritidae) pada beberapa sitem penggunaan di Bukit Rigis, Sumber Jaya, Lampung Barat. J. HPT Tropika. 8(2): 8289.

Nwanze KF, Nwile FE, \& Reddy YVR. 1998. Fecundity and diurnal oviposition behaviour of sorghum shoot fly, Atherigona soccata Rondani (Diptera: Muscidae). Entomon. 23(2): 77-82.

Ogbalu OK. 1999. The effects of different traditional sources of nutrients on the infestation of pepper fruits by the pepper fruitfly, Atherigona orientalis (Schiner) in Nigeria. J. Agron. Crop Sci. 182(1): $65-71$.

Ogbalu OK \& Bob Manuel RB. 2014. Abscission of pepper fruits by dipterous pest, Atherigona orientalis [Schiner] in traditional and mono-crop farms in Port Harcourt, Niger Delta, Nigeria IOSR. J. Agr. Vet. Sci. 7(7): 31-36.

Ogbalu OK, Emelike NJT, Amachree EI, Uche F, \& Thomas CN. 2005a. Characterization and preferred oviposition sites of Atherigona orientalis (Schiner) on Nigeria pepper fruits. $J$. Appl. Sci. Environ. Mgt. 9(1): 19-23.

Ogbalu OK, Emelike JJ, \& Obunwo CC. 2005b. Studies on effects of artificial diets on preoviposition, oviposition period, fecundity and longetivity of Atherigona orientalis (Sciner) (Diptera, Muscidae). J. Applied Sci. 5(10): 1735-1738.

Ogbalu OK, Eze CN, Bob Manuel RB, \& Sokari GM. 2016. The distribution and seasonality of three major frugivorous flies on fruits of economic 
importance at the Port Harcourt Central Grocery. Res. J. Agric. Environ. Mgt. 5(1): 019-031.

Ogbalu OK, Umeozor OC, \& Ebere N. 2005 c. Oviposition deterrents effect of extracts of neem against Atherigona orientalis (Schiner) on pepper (Capsicum annum) and tomato (Lycopersicon esculentum) fruits in Nigeria. Indian J. Agric. Res. 39(1): 18-24.

Ogbalu ON. 1989. The susceptibility of pepper fruits (Capsicum spesies) to oviposition by the pepper fruitfly, Atherigona orientalis (Schiner) in Port Harcourt, Nigeria. Trop. Pest Manage. 35(4): 392-393.

Ogwaro K. 1978. Observation of longevity and fecundity of the sorghum shoot fly, Atherigona soccata (Diptera: Anthomyiidae). Ent. Exp. \& Appl. 23(2): 131-138.

Patitucci LD, Mulieri PR, \& Mariluis JC. 2012. On the identity of Bithoracochaeta sociabilis Blanchard (Diptera: Muscidae): a new synonym of Atherigona orientalis Schiner. Zootaxa. 3487: $85-88$.

Plant Health Australia. 2018. The Australian Handbook for the Identification of Fruit Flies. Version 3.0. Plant Health Australia, Canberra.

Pont AC. 1986. Studies on Australian Muscidae (Diptera). VII. The genus Atherigona Rondani. Australian J. Zool. Suppl. Ser. 120: 1-90.

Pont AC \& Magpayo FR. 1995. Muscid shoot-flies of the Philippine Islands (Diptera: Muscidae, genus Atherigona Rondani). Bull. Entomol. Res. Suppl. 3: 1-121.

Queensland Government. 1998. Tomato Information Kit. Reprint-information current in 1998.

Rabinovich JE. 1970. Vital statistics of Synthesiomyia nudiseta (Diptera: Muscidae). Ann. Entomol. Soc. Amer. 63(3): 749-752.

Raina AK. 1982. Fecundity and oviposition behaviour of the sorghum fruit fly, Atherigona soccata. Entomol. Exp. Appl. 31: 381-385.

Sileshi G. 1997. Biology of the tef shootfly, Atherigona hyalinipennis Van Emden in Eastern Ethiopia. Int. J. Trop. Insect Sci. 17(3-4): 349-355.
Singh N, Singh R, \& Kumar K. 2018. Studies on seasonal incidence of sorghum shoot fly, Atherigona soccata (Rondani) and Stem Borer, Chilo partellus (Swinhoe), in relation to abiotic factor. Int. J. Curr. Microbiol. App. Sci. 7(6): 916-921.

Skidmore P. 1985. The Biology of the Muscidae of the World. Dr. W. Junk Publishers, Dordrecht.

Srivastava RP \& Pandey YD. 1968. Biology of Atherigona oryzae Malloch (Diptera: Anthomyiidae) a new pest of wheat in Rajasthan. Ann. Arid. Zone. 7(1): 132-138.

Suh SJ \& Kwon JY. 2016. First finding of a quarantine pest, Atherigona (Acritochaeta) orientalis Schiner (Diptera : Muscidae), in Korea. Entomol. Res. 46(3): 185-189.

Suh SJ \& Kwon JY. 2017. Taxonomy of the genus Atherigona Rondani (Diptera: Muscidae) from Korea. Entomol. Res. 48(3): 187-197.

Suputa, Trisyono YA, Martono E, \& Siwi SS. 2010. Update on the host range of different species of fruit flies in Indonesia. JPTI. 16(2): 62-75.

Vargas RI \& Nishida T. 1985. Survey for Dacus latifrons (Diptera: Tephritidae). J. Econ. Entomol. 78(6): 1311-1314.

Vijaysegaran S \& Osman MS. 1991. Fruit flies in Peninsular Malaysia: their economic importance and control strategies. In: Kawasaki K, Iwahashi KO, \& Kaneshiro K (Eds.). Proceeding of the International Symposium on the Biology and Control of Fruit Flies. pp. 105-115. Okinawa Perfectural Government, Naha.

Wingsanoi A, Siri N, \& McNeil JN. 2013. The susceptibility of different pepper varieties to infestation by Bactrocera latifrons (Diptera: Tephritidae). J. Econ. Entomol. 106(4): 16481652.

Yamamura N \& Iwahashi O. 1982. Stabilization of the population of a parasite on fruit by the population of cleptoparasite. Res. Popul. Ecol. 24: 345-359. 